OPEN ACCESS

Edited by:

Marty Riche,

Florida Atlantic University, USA

Reviewed by:

Grigorios Krey,

National Agricultural Research Foundation (NAGREF) Hellenic Agricultural Organization (HAO)

DIMITER, Greece

Mohamad N. Azra,

School of Fisheries and Aquaculture

Science, Malaysia

*Correspondence:

Viswanath Kiron

kiron.viswanath@nord.no

Specialty section:

This article was submitted to Marine Fisheries, Aquaculture and

Living Resources,

a section of the journal Frontiers in Marine Science

Received: 12 March 2016 Accepted: 21 April 2016 Published: 17 May 2016

Citation: Kiron V, Sørensen M, Huntley M, Vasanth GK, Gong Y, Dahle D and Palihawadana AM (2016) Defatted Biomass of the Microalga, Desmodesmus sp., Can Replace Fishmeal in the Feeds for Atlantic salmon. Front. Mar. Sci. 3:67. doi: 10.3389/fmars.2016.00067

\section{Defatted Biomass of the Microalga, Desmodesmus sp., Can Replace Fishmeal in the Feeds for Atlantic salmon}

\author{
Viswanath Kiron ${ }^{1 *}$, Mette Sørensen ${ }^{1}$, Mark Huntley $^{2,3}$, Ghana K. Vasanth ${ }^{1}$, \\ Yangyang Gong ${ }^{1,4}$, Dalia Dahle ${ }^{1}$ and Anjana M. Palihawadana ${ }^{1}$
}

\begin{abstract}
${ }^{1}$ Faculty of Biosciences and Aquaculture, Nord University, Bodø, Norway, ${ }^{2}$ Department of Biological and Environmental Engineering, Cornell University, Ithaca, NY, USA, ${ }^{3}$ Marine Laboratory, Nicholas School of the Environment, Duke University, Beaufort, NC, USA, ${ }^{4}$ Key Laboratory of East China Sea and Oceanic Fishery Resources Exploitation, East China Sea Fisheries Research Institute, Shanghai, China
\end{abstract}

Microalgal biomass is a potential feed ingredient that can replace fishmeal and ensure sustainability standards in aquaculture. To understand the efficacy of the defatted biomass from the marine microalga, Desmodesmus sp. a 70-day feeding study was performed with Atlantic salmon (Salmo salar) smolts. Three groups of fish (av. wt. 167 g) were offered either a control feed (without the microalga) or the microalga-containing (10/20\%) feeds. At the end of the feeding period, the growth indices (condition factor, specific growth rate) and survival of the microalga-fed fish were not significantly different from the respective values of the control fish, but the feed conversion ratios were inferior. The proximate composition of the whole body of salmon from the three groups did not vary significantly. Compared to the control fish, the $10 \%$ alga-fed fish had lower lipid content in their filet. The protein and lipid digestibility in the three feeds did not differ significantly, but the digestibility of energy in the 10\% alga-feed was significantly lower than that of the control feed. Furthermore, comparison of the distal intestinal proteome of Atlantic salmon revealed that the expressions of Alpha-2-HS-glycoprotein-like (Ahsg), Myosin-11 isoform X1 (My11) and Dihydrolipoyl dehydrogenase, mitochondrial-like (Dld) were altered by the microalgal feeding. Examination of the physiological status of the fish based on the serum antioxidant capacities did not reveal any alga-feed-related differences. Moreover, the expression of the selected immune and inflammatory marker genes and the micromorphological observations did not indicate any aberration in the intestinal health of the microalga-fed fish. It is possible to include $20 \%$ of defatted Desmodesmus sp. in the feeds of Atlantic salmon.

Keywords: Atlantic salmon, microalga, Desmodesmus, feed ingredient, fishmeal replacement, growth, feed performance, intestinal health 


\section{INTRODUCTION}

Production of farmed aquatic species has increased significantly and therefore the aquafeed industry is actively engaged in finding alternatives for the highly used fishmeal. Such a strategy is imperative for the sustainable growth of the aquaculture industry. The aquafeed sector has been using terrestrial plant-derived ingredients as substitutes for fishmeal and fish oil in the feeds of various farmed fish including those for Atlantic salmon, Salmo salar. Terrestrial plant ingredients employed in the feeds of Atlantic salmon include soyprotein concentrate, sunflower expeller, wheat gluten, fava beans, pea protein, maize gluten, horse beans, rapeseed oil, wheat starch, pea starch and tapioca starch (Ytrestøyl et al., 2015). However, some of these ingredients can compromise the intestinal health of carnivorous species like Atlantic salmon (Baeverfjord and Krogdahl, 1996; Knudsen et al., 2007; Bakke, 2011). Hence, it would be ideal to use ingredients from microalgae, which are present in the aquatic food web, in the feeds of Atlantic salmon.

Microalgae are rich in essential nutrients and bioactive molecules, and therefore, are valuable nutrient sources for humans and animals (Becker, 2004). They contain highquality protein, $50-70 \%$ of which is likely to be bioavailable to animals (Becker, 2007). The bioactive components include polyunsaturated fatty acids, sugars, polysaccharides, vitamins, minerals, and pigments (Becker, 2004). Thus, microalgae can be high quality feed components.

In Europe and the United States, efforts are underway to commercially exploit the full potential of microalgae (Enzing et al., 2014; Energy.Gov: Office of Energy Efficiency Renewable Energy, 2016). The co-products from the cultivated microalgae such as Staurosira sp. and Desmodesmus sp. include "biocrude" oil and residual protein-rich fractions (Huntley et al., 2015). The defatted protein-rich biomass obtained after the extraction of the biofuel could serve as an ingredient in animal feeds. Even though some studies have proved the potential of using microalgae in fish feeds, the protein quality of an alga can be determined only through elaborate feeding studies on animals (Becker, 2004). The effect of current plant-derived fishmeal replacers on farmed animals varies widely. Therefore, feeding studies should evaluate the potential of the microalgae products as fishmeal substitutes by investigating not only the growth of the animals but also their health status.

In the present study, the ability of the defatted biomass of Desmodesmus sp. to replace fishmeal in the feeds of Atlantic salmon was evaluated by assessing the growth, feed performance, antioxidant status, and intestinal health of the fish. The hypothesis is that the Desmodesmus biomass in the feeds of Atlantic salmon could impart good growth and health to the fish.

\section{MATERIALS AND METHODS}

\section{Fish and Rearing}

The study was approved by the National Animal Research Authority (FDU: Forsøksdyrutvalget ID - 5887) in Norway. The fish rearing and handling procedures were according to the approved protocols of FDU.
Atlantic salmon, Salmo salar smolts obtained from Cermaq, Hopen, Bodø, Norway were maintained on commercial feeds at the Research Station of the Nord University, Bodø, Norway for 2 months. Before the start of the feeding experiment, the fish were transferred to the indoor rearing tanks $(800 \mathrm{~L})$, which were part of a flow-through seawater system. The tanks had feed traps (Aquatic Eco-Trap, Pentair Aquatic Eco-Systems ${ }^{\circledR}$, Florida, USA) to collect the uneaten feed. Each of the 18 tanks used for the study was stocked with 25 fish of average weight $167.6 \mathrm{~g}$. The temperature $\left(7.6 \pm 0.9^{\circ} \mathrm{C}\right)$ and dissolved oxygen saturation (av. 90\%) of the rearing water were recorded daily. A 24-h light regime was employed throughout the experimental period.

\section{Experimental Feeds, Design and Feeding}

The three types of experimental feeds (one control feed and two microalgal feeds, Table 1) were made to order (Center for Feed Technology, Norwegian University of Life Sciences, Ås, Norway). In the algal feeds, the algal biomass of Desmodesmus sp., a coproduct from biofuel production (Cellana, San Diego, USA), replaced a portion of the fishmeal. The extruded feed pellets ( 3 $\mathrm{mm}$ size) were stored at $4^{\circ} \mathrm{C}$ until they were used for feeding the fish.

The three fish groups in this study were: a control group that received alga-devoid feed (4C), and 2 alga-fed groups that were offered feeds containing the defatted Desmodesmus biomass at inclusion levels of $10 \%(4 \mathrm{~L})$ and $20 \%(4 \mathrm{H})$. Fish in six tanks were randomly allotted to one feed group and they were offered the respective feeds daily for a period of 10 weeks. Automatic feeder (Arvo-Tec, Huutokoski, Finland) of a particular tank was programmed to deliver daily doses of feed (until the end of the study) corresponding to $1.2 \%$ of the body mass of fish in the tank. The daily ration was delivered intermittently, between 08:00 and 09:00, and between 14:00 and 15:00. The left-over feeds were collected from the trap, $1 \mathrm{~h}$ after each meal. They were then dried

TABLE 1 | Ingredients and proximate composition of the experimental feeds.

\begin{tabular}{lccc}
\hline Feed ingredients (g/100 g) & \multicolumn{3}{c}{ Experimental feeds } \\
\cline { 2 - 4 } & $\mathbf{4 C}$ & $\mathbf{4 L}$ & $\mathbf{4 H}$ \\
\hline Fish meal & 69 & 60 & 51 \\
Algal meal & 0 & 10 & 20 \\
Wheat & 12 & 12 & 12 \\
Wheat gluten & 5 & 5 & 5 \\
Fish oil & 13.5 & 12.5 & 11.5 \\
Microingredients & 0.5 & 0.5 & 0.5 \\
Marker (Yttrium) & 0.01 & 0.01 & 0.01 \\
Proximate composition (g/100 g dry & basis) & & 7.1 \\
Moisture & 3.5 & 7.6 & 47.8 \\
Crude protein & 53.8 & 50.4 & 19.5 \\
Crude lipid & 20.1 & 19.8 & 12.2 \\
Ash & 11.1 & 11.5 & 2.3 \\
Energy (MJ/100g) & 2.3 & 2.3 & \\
\hline
\end{tabular}

*Vitamin and mineral mix is a proprietary formulation of Polarfeed, Leknes, Norway. 
and weighed to determine the actual feed intake. The fish in the tanks were visually inspected in the afternoon, after the feeding session, to ascertain their well-being.

\section{Sampling}

At the start of the experiment, individual weights and lengths of the fish were recorded. The fish were starved for $24 \mathrm{~h}$ and anesthetized with MS-222 (Tricaine methane sulphonate; Argent Chemical Laboratories, Redmond, USA; $80 \mathrm{mg} / \mathrm{l}$ ), prior to taking the measurements. Similarly, the final weights and lengths were recorded at day 70. Representative samples were collected at day 70 from fish in all tanks-blood (serum), distal intestine, filet and whole body-to assess the different parameters of interest. In addition, the weight of the visceral organs and liver of the sampled fish were recorded. After the termination of the feeding study, the feces for the digestibility determination was collected by stripping the fish, as described by Austreng (1978). Feces from individual fish in one tank of a particular group were pooled during collection. Prior to chemical analysis, freeze-dried feces from two tanks had to be pooled to get enough material for analyses. The sample size is indicated in the figure legends and table footnotes.

\section{Study Parameters Growth and Feed Performance}

Initial and final weights, and feed consumption of the fish were used to calculate the growth and feed performance indices. The formulae for calculating the condition factor, specific growth rate (SGR), feed conversion ratio (FCR), protein efficiency ratio (PER) and survival are provided in the footnote of Table 3.

Hepatosomatic index $[$ HSI $=$ (liver weight/final weight) $\times 100$ ] and viscerosomatic index [VSI $=$ (visceral organ weight/final weight $) \times 100$ ] of the fish from different groups were calculated.

To determine the proximate composition of the whole body and filet, the samples were thawed and homogenized in a grinder (Grindomix GM 200, Retsch, Haan, Germany). Moisture (gravimetry), ash (incineration at $550^{\circ} \mathrm{C}$ ), crude protein ( $\mathrm{N}^{*} 6.25$, Kjeldahl Autoanalyser, Tecator, Sweden) and total lipid (in fish -ethyl acetate extraction method, Norges Standardiseringsforbund, 1994) contents of the fish and the feeds were determined using standard protocols (Kiron et al., 2012). The energy content in the feeds and feces were determined by bomb calorimetry (C200 calorimeter, IKA, Staufen, Germany). The total lipid and yttrium content in the feeds and feces were determined by Eurofins AS (Moss, Norway) and they were used to calculate the digestibility coefficients. The total lipid content was determined using the Soxhlet method with acid hydrolysis. Yttrium content was analyzed after combustion of the samples at $550^{\circ} \mathrm{C}$ and boiling with hydrochloric acid and nitric acid. Thereafter the samples were cooled and dissolved in 5\% nitric acid. Yttrium was then detected with a spectrometer (Perkin Elmer, Massachusetts, USA).

\section{Histological Studies}

The processing and sectioning techniques of the distal intestinal samples ( $n=6$ fish) are described in Vasanth et al. (2015).
Approximately $5 \mu \mathrm{m}$ sections were fixed for the histological studies. The sections were stained with Alcian Blue-Periodic Acid Schiff's reagent (AB-PAS, pH 1.0) (Bancroft and Gamble, 2007). Photomicrographs were captured employing an Olympus BX61/Camera Color View IIIu (Olympus Europa GmbH, Hamburg, Germany) and processed using the imaging system, photo program Cell P (Soft Imaging System GmbH, Munster, Germany).

\section{Antioxidant Indices}

The frozen $\left(-80^{\circ} \mathrm{C}\right)$ serum aliquots were thawed prior to conducting the different assays, which were performed using commercially available kits employing a microtiter plate (Nuclon sterile 96 flat, Fisher Scientific, Massachusetts, USA). The respective absorbances were measured at the suggested wavelengths employing a microplate reader (Fluostar Optima; BMG Labtech, Ortenberg, Germany).

Total antioxidant capacity (TAC): Aliquots $(20 \mu \mathrm{L})$ of the serum samples were used for determining the TAC, employing a kit from Cell Biolabs (STA-360, Cell Biolabs Inc., San Diego, CA, USA). The initial and final absorbances $(490 \mathrm{~nm})$ of the samples and standards were measured, and based on the net absorbance values and the uric acid standard curve, the uric acid equivalence (UAE) of the samples was obtained. The $\mu \mathrm{M}$ copper reducing equivalents (CRE), which is proportional to TAC, were calculated by multiplying the UAE concentrations by a factor of $2189 \mu \mathrm{M}$ $\mathrm{Cu}++/ \mu \mathrm{M}$ uric acid.

Catalase (CAT) activity: The Cayman Chemicals assay kit 707002 (Cayman Chemicals, Ann Arbor, Michigan, USA) was employed to determine the CAT activity of serum aliquots (20 $\mu \mathrm{L}$ ), following the manufacturer's protocol. The enzyme activity was calculated based on the absorbance at $540 \mathrm{~nm}$ and the formaldehyde standard curve. The activity $(\mathrm{nmol} / \mathrm{min} / \mathrm{ml})$ is expressed as the amount of enzyme that will cause the formation of $1.0 \mathrm{nmol}$ of formaldehyde per minute at $25^{\circ} \mathrm{C}$.

Superoxide dismutase (SOD) activity: A commercially available kit (STA-340, Cell Biolabs Inc.) was employed to determine the SOD activity in $20 \mu \mathrm{L}$ serum samples. The assay was performed following the manufacturer's instructions. The SOD activity (inhibition \%) of the sample is inversely proportional to the colorimetric signal and is calculated using the absorbance values of the sample and blank at $490 \mathrm{~nm}$. The activity is expressed as SOD units $\mathrm{U} / \mu \mathrm{L}$.

\section{Gene Expression Study}

The mRNA levels of selected genes - antioxidant-related (superoxide dismutase1 - sod1; nuclear factor erythroid 2related factor - nrf2), mucosa-related (immunoglobulin $T$ - igt), inflammation-related (interleukin $1 b$ - il1b; interleukin 10 - il10; interleukin $17 a$ and $17 d$ - il17a, il17d; transforming growth factor beta - tgfb; tumor necrosis factor a - tnfa), antimicrobial (cathelicidin 1 and 2 - cathl1, cathl2; defensin beta 2 - defb2) - were assessed in this study.

\section{RNA extraction and cDNA synthesis}

The total RNA from the distal intestine was extracted using E-Z 96 Total RNA Kit (OMEGA Bio-Tek Inc., Norcross, GA, USA), 
following the instructions of the manufacturer. About $100 \mathrm{mg}$ of the tissue was homogenized with Zirconium oxide beads (1.4 $\mathrm{mm}$; Percellys, Tarnos, France) in TRK lysis buffer in a precooled free standing tube (VWR International, Oslo, Norway) at 6000 $\mathrm{rpm}$. The resulting crude mixture was centrifuged $(18,000 \times \mathrm{g}$, $20^{\circ} \mathrm{C}$ ) and approximately $300 \mu \mathrm{l}$ of the supernatant was collected and mixed with equal volume of $70 \%$ ethanol. This mixture was added to the assigned wells of the E-Z 96 RNA plate mounted on an E-Z 96 ${ }^{\circledR}$ Vacuum Manifold (VAC-03, Omega Bio-tek Inc.). A pressure of $1100 \mathrm{kPa}$ was applied to draw the sample through the well, which had an RNA HiBind ${ }^{\circledR}$ matrix. This step was followed by buffer washes; first with RWF Wash Buffer $(500 \mu \mathrm{l})$ and then twice with $600 \mu \mathrm{L}$ of RNA Wash Buffer II. Pressure was applied each time the wells were treated with the wash buffers. Finally, the purified RNA was recovered from the HiBind ${ }^{\circledR}$ matrix by adding $50 \mu \mathrm{l}$ of RNase-free water ( 5 Prime GmbH, Hilden, Germany) to each well and applying a final round of pressure.

The cDNA was synthesized as described by Vasanth et al. (2015). The obtained cDNA was 30-fold diluted and used in qPCR.

\section{Real-time PCR (qPCR) and the quantification of gene expression}

The primers for the reference and target genes are given in Table 2. The PCR reactions were carried out using LightCycler ${ }^{\circledR} 96$ Real-Time PCR System (Roche Holding AG, Basel, Switzerland). Each reaction from one fish sample was done in duplicate, and to quantify the mRNA level of a particular gene, reactions were done on samples from 12 fish (2 from each tank). All the reactions were performed using a total volume of $10 \mu \mathrm{l}$, containing $5 \mu \mathrm{l}$ of FastStart Universal SYBR Green Master (ROX) mixed with $1 \mu \mathrm{l}$ primer mix (200 nM), and $4 \mu \mathrm{l}$ cDNA $(5 \mathrm{ng} / \mu \mathrm{l})$. Each reaction was done under the following thermal cycling conditions: preincubation at $95^{\circ} \mathrm{C}$ for $600 \mathrm{~s}$ followed by 40 cycles of two step amplification at $95^{\circ} \mathrm{C}(10 \mathrm{~s})$, and $60^{\circ} \mathrm{C}(30 \mathrm{~s})$ and melting at $95^{\circ} \mathrm{C}(10 \mathrm{~s}), 65^{\circ} \mathrm{C}(60 \mathrm{~s})$ and $97^{\circ} \mathrm{C}(1 \mathrm{~s})$. Specificity of the amplified products was checked by performing melt curve analyses for each sample and the specificity of the primers was confirmed by sequencing the amplified products. For relative quantification, the total RNA from all samples was pooled, and normalized to $1000 \mathrm{ng}$, from which a 6-point 3-fold serial dilution was prepared (1:1 to $1: 243)$ to make a standard curve. The efficiency of the primers was calculated using the equation $E=\left(10^{-1 / \mathrm{m}}-1\right) 100$. A normalization factor was computed for each of the samples based on the relative quantities of the two most stable genes, rpl13 and rps29 from among the set of four reference genes-elongation factor $1 a b$ (eflab), ribosomal protein L13 (rpl13), ribosomal protein S29 (rps29) and ubiquitin (ubi), employing geNorm (Vandesompele et al., 2002). The expression levels of all the target genes were then calculated relative to the normalization factor.

\section{Protein Expression Study}

Two-dimensional electrophoresis (2-DE) was performed on the distal intestinal samples ( $n=6$ fish from 6 tanks) from each of the three groups. The various steps such as protein extraction, two-dimensional electrophoresis and capturing of the gel images are described previously (Vasanth et al., 2015).

The gel images were analyzed using SameSpots (Totallab, Newcastle, UK). The spots were automatically aligned and those with significantly different volumes (with a minimum foldchange of 1.5 and statistical significance at $p<0.05$ ) were selected as the spots of interest.

To identify the proteins corresponding to the selected spots, $300 \mu \mathrm{g}$ of protein was loaded onto a preparative Sypro $\AA$ Ruby stained gel. The selected spots were excised, and sent to the Tromsø University Proteomics Platform (TUPP), Norway-for performing liquid chromatography and tandem mass spectrometry (LC-MS/MS). The peak list files obtained from TUPP were used to determine the protein identity. Mascot search engine (version 2.5.00) was used to search the NCBInr database or the whole genome sequences fasta files from NCBI. The search gave the matched peptides of Atlantic salmon. At least two unique peptides were considered for the protein inference and contaminants were eliminated from the search list.

\section{Statistical Analysis}

GraphPad Prism V6.03 was used to carry out the statistical analyses. The tanks were considered as the experimental units. Normality of the data was tested by KS normality test, and the assumption of equal variance was checked by the Brown-Forsythe test. One-way ANOVA followed by Tukey's multiple comparisons test was employed to detect the significant differences between the means of interest. For non-parametric data, the Kruskal-Wallis test followed by Dunn's multiple comparisons test was employed to understand the difference between the study groups.

\section{RESULTS}

\section{Growth and Feed Performance}

The experimental feeds (Table 1) were formulated to provide the nutrient and energy needs of Atlantic salmon. At the end of the feeding period, the fish of $4 \mathrm{C}, 4 \mathrm{~L}$, and $4 \mathrm{H}$ attained mean weights of $359,344,360 \mathrm{~g}$, respectively, compared to the initial weight of $167 \mathrm{~g}$ (Table 3). The condition factors of the $4 \mathrm{C}, 4 \mathrm{~L}$, and $4 \mathrm{H}$ groups were $1.06,1.05$, and 1.05 , respectively. The viscero- and hepato-somatic indices of the alga-fed groups were not significantly different from the values of the control group (Table 3). The SGR of the alga-fed groups were similar to that of the control group. The FCR was significantly lower for the control group compared to the algae-fed groups. PER also did not vary significantly among the groups.

The protein and lipid digestibility of the experimental feeds did not differ significantly. The digestibility of energy in the $10 \%$ alga-containing feed was lower compared to that of the control feed (Table 4).

The proximate composition of the whole body of fish from the alga-fed groups was similar to that of the control group (Table 5). In the case of the filet from fish fed $10 \%$ of the alga the lipid content was lower compared to the control group. Furthermore, the ash content of the filet of fish fed $20 \%$ of the alga was relatively lower compared to those of the control group and the fish fed 10\% 
TABLE 2 | List of primers for the differentially expressed genes and reference genes.

\begin{tabular}{|c|c|c|c|c|}
\hline Gene name & Sequence $\left(5^{\prime}-3^{\prime}\right)$ & Amplicon size (bp) & PCR efficiency (\%) & Reference \\
\hline sod1 & CCACGTCCATGCCTITGG F TCAGCTGCTGCAGTCACGTT R & 141 & 95.3 & GenBank : AY736282.1 \\
\hline nif2 & TCAACAGGACATCGACCTAAT F GGCAGTAGTCAAACACCTCT $\mathbf{R}$ & 83 & 91.2 & GenBank : BT059007.1 \\
\hline cath/1 & CTAGCAACAACCTGAACACTG F CTTCTTGTCCGAATCTTCTGCATA R & 88 & 96.4 & GenBank : AY728057.1 \\
\hline cath/2 & TGCTTCAAATCAGCTGCTTCC F CTGTATTCAAAGTCTCGACTTCCA R & 83 & 104.4 & GeneBank : AY542961.1 \\
\hline$i / 17 d$ & CTTGTCTCCCTGGGCATACAG F CAATATGCCTCGGGTATGAACCT R & 201 & 112.7 & GenBank : EU689087.1 \\
\hline $\operatorname{tgfb}$ & GGTACTGGCTCTGTATAAGCAC F CTGCTCCACCTTGTGTTGTC $\mathbf{R}$ & 120 & 100.9 & GenBank : BT059581 \\
\hline igt & CAACACTGACTGGAACAACAAGGT F CGTCAGCGGTTCTGTITGGA R & 97 & 107.7 & GenBank : GQ907004 \\
\hline \multicolumn{5}{|c|}{ REFERENCE GENES } \\
\hline ef1ab & TGCCCCTCCAGGATGTCTAC F CACGGCCCACAGGTACTG R & 59 & 96 & GenBank : BG933853 \\
\hline rp/13 & CGCTCCAAGCTCATCCTCTTCCC $\mathbf{F}$ CCATCTTGAGTTCCTCCTCAGTGC $\mathbf{R}$ & 79 & 96.4 & GenBank : BT048949.1 \\
\hline rps29 & GGGTCATCAGCAGCTCTATTGG F AGTCCAGCTTAACAAAGCCGATG R & 167 & 94.5 & GenBank : BT043522.1 \\
\hline ubi & AGCTGGCCCAGAAGTACAACTGTG F CCACAAAAAGCACCAAGCCAAC $\mathbf{R}$ & 162 & 92.7 & GenBank : AB036060.1 \\
\hline
\end{tabular}

TABLE 3 | Growth, feed performance, organosomatic indices and survival rate of Atlantic salmon from the different groups.

\begin{tabular}{lccc}
\hline & 4C & 4L & 4H \\
\hline Initial weight (g) & $166.61 \pm 2.10$ & $165.90 \pm 1.95$ & $170.30 \pm 2.00$ \\
Final weight (g) & $358.60 \pm 3.16^{\mathrm{a}}$ & $343.90 \pm 4.61^{\mathrm{b}}$ & $359.80 \pm 4.57^{\mathrm{a}}$ \\
Condition factor & $1.06 \pm 0.01$ & $1.05 \pm 0.01$ & $1.05 \pm 0.02$ \\
SGR (\% day-1) & $1.10 \pm 0.01$ & $1.04 \pm 0.01$ & $1.07 \pm 0.01^{\mathrm{b}}$ \\
FCR (g feed/g gain) & $0.81 \pm 0.01^{\mathrm{a}}$ & $0.86 \pm 0.01^{\mathrm{b}}$ & $0.90 \pm 0.01^{\mathrm{b}}$ \\
PER & $2.29 \pm 0.03$ & $2.32 \pm 0.03$ & $2.36 \pm 0.03$ \\
HSI & $1.30 \pm 0.08$ & $1.29 \pm 0.08$ & $1.30 \pm 0.05$ \\
VSI & $8.11 \pm 0.26$ & $8.06 \pm 0.36$ & $8.29 \pm 0.24$ \\
Survival (\%) & 100 & $99.33 \pm 0.67$ & 100 \\
\hline
\end{tabular}

$n=6$ tanks, values from 25 fish/tank, mean \pm s.e.m. Different superscripts in a row indicate statistically significant differences.

Condition factor, $C F=\left(\right.$ Final weight/Total length $\left.{ }^{3}\right) \times 100$

Specific growth rate, SGR $=100 \times($ (In Final mean fish weight in a tank - In Initial mean fish weight in a tank)/Number of feeding days)

Feed conversion ratio, FCR $=$ (Apparent feed intake in dry basis/(Final biomass-Initial biomass + Biomass of dead fish))

Protein efficiency ratio, PER $=(($ Final biomass-Initial biomass $) /$ Protein intake $)$

Survival $=100 \times$ (Final fish number/Initial fish number).

TABLE 4 | Digestibility of the different feeds.

\begin{tabular}{lccc}
\hline & $\mathbf{4 C}$ & $\mathbf{4 L}$ & $\mathbf{4 H}$ \\
\hline Protein & $84.57 \pm 0.33$ & $83.08 \pm 0.47$ & $83.61 \pm 0.32$ \\
Lipid & $89.04 \pm 1.74$ & $88.30 \pm 1.05$ & $93.55 \pm 0.16$ \\
Energy & $81.02 \pm 0.75^{\mathrm{a}}$ & $78.28 \pm 0.63^{\mathrm{b}}$ & $79.70 \pm 0.07^{\mathrm{ab}}$ \\
\hline
\end{tabular}

All values are calculated using the dry basis values.

Faeces from 23 fish/tank were pooled and freeze dried. Faeces from 2 tanks of a particular group were pooled prior to analysis; $n=3$, mean \pm s.e.m. Different superscripts in a row indicate statistically significant differences.

of the alga. The protein content in the whole body and filet of the alga-fed groups were higher and lower, respectively, compared to the control group, although not statistically significant.
TABLE 5 | Proximate composition of Atlantic salmon ( $\mathrm{g} / 100 \mathrm{~g}$ dry basis) from the different groups.

\begin{tabular}{lcccc}
\hline Group & Moisture & Protein & Lipid & Ash \\
\hline WHOLE BODY & & & \\
Initial & $74.75 \pm 0.51$ & $65.89 \pm 1.17$ & $27.66 \pm 1.30$ & $8.94 \pm 0.31$ \\
Final & & & & \\
$4 \mathrm{C}$ & $69.13 \pm 0.30$ & $56.44 \pm 0.73$ & $32.68 \pm 0.91$ & $6.21 \pm 0.21$ \\
4L & $68.77 \pm 0.49$ & $57.81 \pm 1.01$ & $31.76 \pm 0.80$ & $6.62 \pm 0.23$ \\
4H & $68.64 \pm 0.32$ & $58.02 \pm 0.43$ & $32.46 \pm 0.82$ & $6.57 \pm 0.21$ \\
FILLET & & & & \\
Initial & $73.17 \pm 0.67$ & $78.94 \pm 2.07$ & $7.48 \pm 0.30$ & $6.07 \pm 0.37$ \\
Final & & & & \\
$4 \mathrm{C}$ & $73.84 \pm 0.22$ & $79.71 \pm 1.30$ & $16.73 \pm 0.56^{\mathrm{a}}$ & $6.76 \pm 0.24^{\mathrm{a}}$ \\
4L & $73.08 \pm 0.39$ & $75.00 \pm 1.97$ & $12.75 \pm 0.39^{\mathrm{bc}}$ & $6.53 \pm 0.08^{\mathrm{a}}$ \\
4H & $73.47 \pm 0.25$ & $75.19 \pm 1.20$ & $14.84 \pm 0.75^{\mathrm{ac}}$ & $5.57 \pm 0.18^{\mathrm{b}}$
\end{tabular}

$n=6$ tanks, values from 6 fish/tank; mean \pm s.e.m. Different superscripts in a column indicate statistically significant differences.

\section{Antioxidant Status}

The total antioxidant capacity as well as the catalase activity of the alga-fed fish was similar to that of the control group (Figure 1). The superoxide dismutase activity of the alga-fed groups was higher than that in the control group, although a statistical significance was not detected (Figure 1). In addition, the mRNA levels of sod 1 and $n r f 2$ in the different experimental groups were similar (Figure 2).

\section{Intestinal Health}

Concerning the expression of the selected genes in the distal intestine of Atlantic salmon, the mRNA levels of the gut mucosalinked immunoglobulin igt in the alga-fed groups were similar to that of the control group (Figure 2). The expression of inflammation-related genes, $i l 1 b, i l 17 a, i l 10, \operatorname{tnfa}$ were below the detection limit. The mRNA levels of $i l 17 d$ in the alga-fed groups were similar to the value in the control group (Figure 2). The expression of $t g f b$ was similar in all the groups (Figure 2). Among the antimicrobial genes examined, the expression of defb2 was 

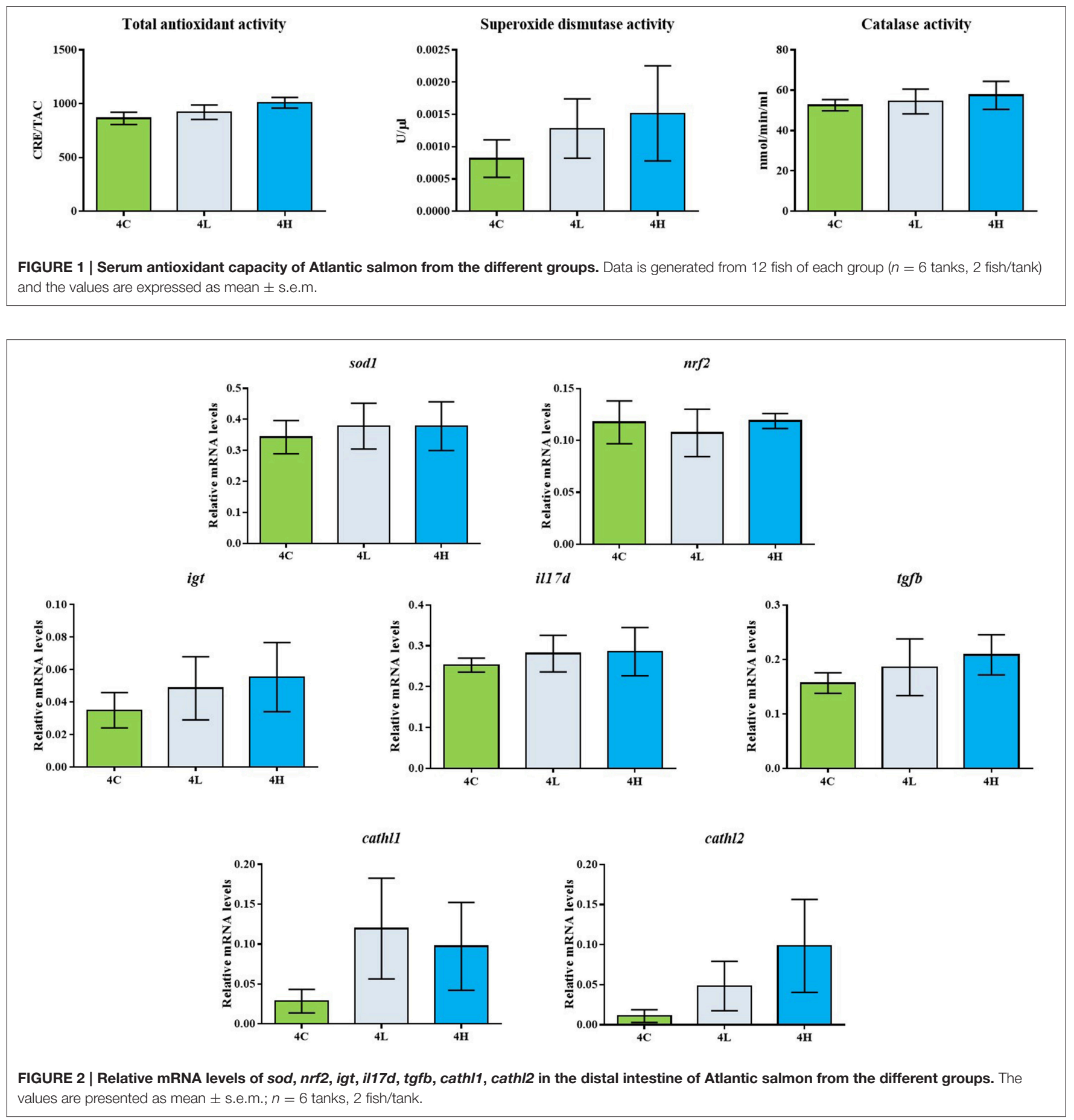

not detectable. The expression of cathl1 and cathl2 were higher in the alga-fed groups compared to the values of the control group (Figure 3). However, a statistical significance was not detected.

Analysis of the intestinal proteome of Atlantic salmon revealed that the expressions of Alpha-2-HS-glycoprotein- like (Ahsg), Myosin-11 isoform X1 (My11), Dihydrolipoyl dehydrogenase, mitochondrial-like (Dld) were altered by algal feeding (Figure 3, Table 6; Supplementary Figure 2). Dld was underexpressed in the alga-fed groups $(10 \%-0.45$-fold, $p<0.05$; $20 \%-0.49$-fold, $p>0.05)$ compared to the expression in the control group. Ahsg was underexpressed in the alga-fed groups 

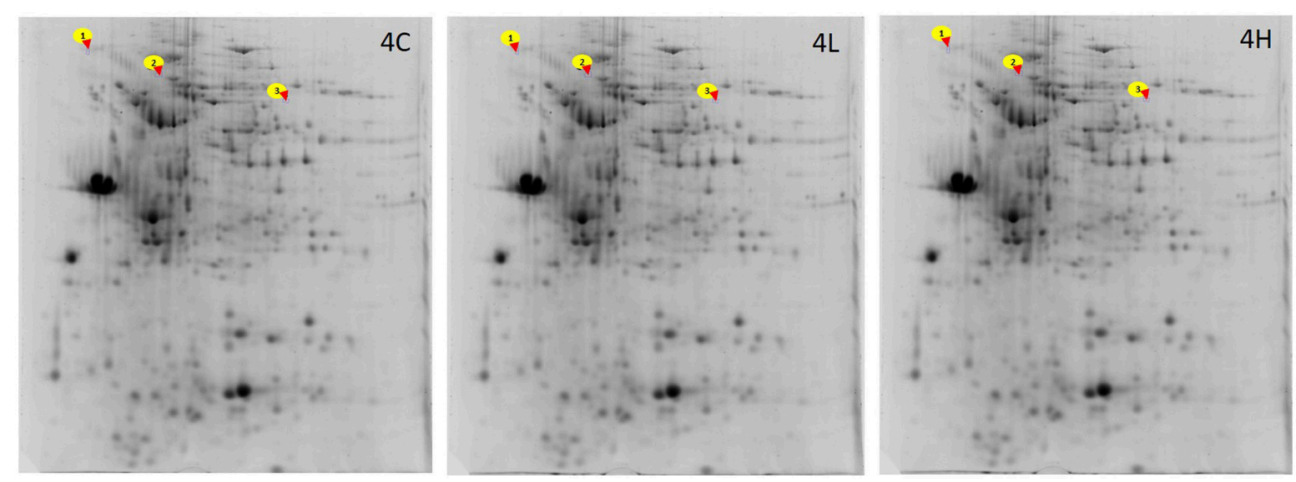

FIGURE 3 | Representative 2-DE gels showing the spots of proteins from the distal intestine of Atlantic salmon. For generating the gels, the intestinal proteins from the distal intestine of Atlantic salmon from the 4C, 4L, and $4 \mathrm{H}$ groups were first isoelectrically focused on $17 \mathrm{~cm} \mathrm{IPG} \mathrm{strips} \mathrm{(pl} \mathrm{3-10)} \mathrm{and} \mathrm{then} \mathrm{subjected}$ to $12.5 \%$ SDS-PAGE. The Sypro®Ruby protein gel stain was used to stain the gels. The spots 1, 2, and 3 corresponds to Ahsg, My 11 and Dld, respectively (see Table 6). $n=6$ tanks, 1 fish/tank.

TABLE 6 | Information of the proteins that were differentially expressed in the distal intestine of Atlantic salmon from different groups.

\begin{tabular}{|c|c|c|c|}
\hline $\begin{array}{l}\text { Spot } \\
\text { no. }\end{array}$ & Protein name & $\begin{array}{l}\text { Apparent } \\
\text { pl/MW (kDa) }\end{array}$ & Peptides $^{a}$ \\
\hline $1 V$ & $\begin{array}{l}\text { Alpha-2-HS- } \\
\text { glycoprotein-like } \\
\text { (Ahsg) }\end{array}$ & $3.2 / 143.5$ & $\begin{array}{l}\text { YALNQIDDIK } \\
\text { VVTAVEGDCDVVLR } \\
\text { KVGGVMSVTAFK } \\
\text { VGGVMSVTAFK } \\
\text { ESLFAIMEVGR }\end{array}$ \\
\hline $2 v$ & $\begin{array}{l}\text { Myosin-11 isoform X1 } \\
\text { (My11) }\end{array}$ & $5.1 / 99.9$ & $\begin{array}{l}\text { DVSTLSAQVQDTQELLAEETR } \\
\text { NSLQEQLEEEVEAK } \\
\text { KLEEMAGNNELLEESK } \\
\text { DLEASNTQFEEK } \\
\text { KFDQMLAEEK } \\
\text { ALEEAQDSREELER } \\
\text { TEMEDLVSSK } \\
\text { GLEAQVEEMK } \\
\text { LEVNMQALK } \\
\text { ELETELEDER } \\
\text { DLEGQIEMSNK } \\
\text { ISQLEEELEESSNMEILNDR } \\
\text { KSTQQVDQLNNELQTER } \\
\text { STQQVDQLNNELQTER }\end{array}$ \\
\hline $3 v$ & $\begin{array}{l}\text { Dihydrolipoyl } \\
\text { dehydrogenase, } \\
\text { mitochondrial-precursor } \\
\text { (Dld) }\end{array}$ & 7.6/88.6 & $\begin{array}{l}\text { GIEISGITLNLEK } \\
\text { VTAVEFLGHVGGLGIDMEISK } \\
\text { RPDGQIDVAVEAAAGGK } \\
\text { NLGLDTVGLELDNR } \\
\text { VPSIYAIGDVIAGPMLAHK } \\
\text { EANLAASFGK }\end{array}$ \\
\hline
\end{tabular}

aUnique peptides in bold; $V$ indicates underexpression in the algal groups compared to the control group.

(0.55 and 0.50 -fold, $p<0.05$ ) compared to the protein expression in the control group. My11 was underexpressed in the $20 \%$ algafed group $(0.6$-fold, $p<0.05)$ compared to the expression in the control group.

Algal feeding did not affect the distal intestinal morphology of Atlantic salmon. The normal structure of lamina propria and the appearance of goblet cells are evident from the photomicrographs (Figure 4; Supplementary Figure 1).

\section{DISCUSSION}

The present study reports the effects of replacement (10 or $20 \%$ ) of fishmeal with the microalgal biomass of Desmodesmus sp. in the feeds of Atlantic salmon. Desmodesmus-containing feeds did not significantly alter the specific growth rate and health indices of Atlantic salmon.

Atlantic salmon is a carnivorous fish and requires quality protein for their normal growth and development. As per the National Research Council report, Atlantic salmon should be provided with $36 \%$ digestible protein via feeds (National Research Council of the National Academies, 2011). The experimental feeds used in the present study had protein content (dry basis) in the range $478-538 \mathrm{~g} / \mathrm{kg}$.

\section{Growth and Feed Conversion Efficiency upon Feeding Desmodesmus to Atlantic salmon}

Overall, the fish performed well, and the weights of the fish after 70 days were twice that of the initial values. The results indicate that defatted Desmodesmus sp. can be included (up to $20 \%)$ in the feeds for Atlantic salmon. The final weights of the $4 \mathrm{C}$ and $4 \mathrm{H}$ groups were similar while that of the $4 \mathrm{~L}$ group was significantly lower than that of the other groups. Higher FCR of the alga-fed groups indicates that nutrient availability in the alga-containing feeds was poorer than that in the $4 \mathrm{C}$ feed, although this was reflected only in the energy digestibility of the $4 \mathrm{~L}$ group. Different studies have reported the effects of feeding algae to omnivorous fish. Nile tilapia (Oreochromis niloticus) larvae/juveniles, when fed with $44 \%$ Spirulina for 11 weeks, had higher SGR and PER, and good FCR values compared to the corn gluten-based control feed (Hussein et al., 2013). The fry of the same fish fed on $10 \mathrm{~g}$ of live Spirulina (Arthrospira platensis)/kg of feed had optimum growth and feed efficiency (Abdel-Tawwab 

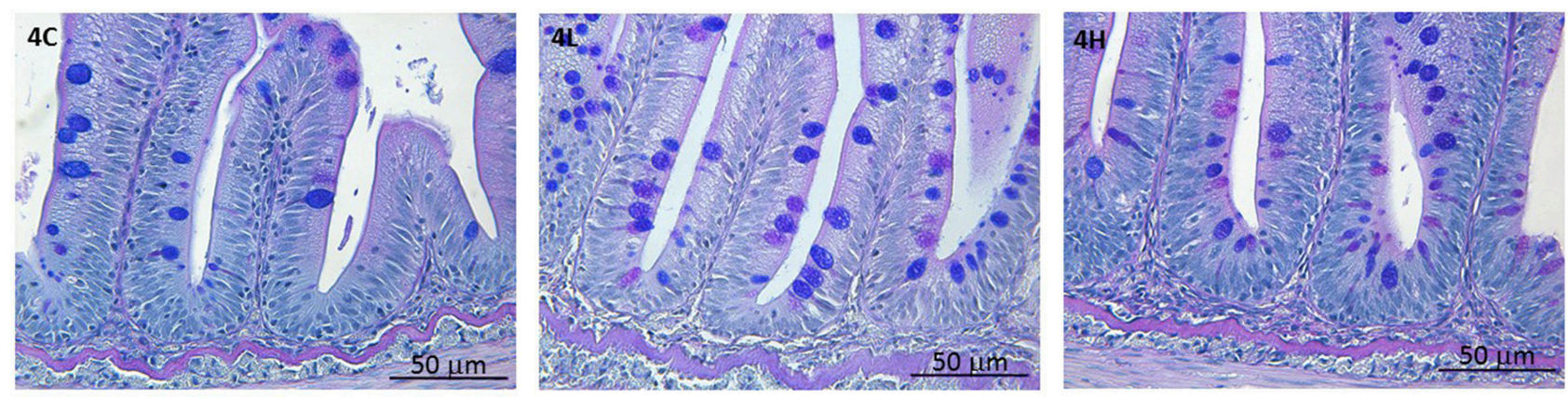

FIGURE 4 | Photomicrographs of the distal intestine of Atlantic salmon from the different groups. Representative images show the normal architecture of the intestine. Scale bar: $50 \mu \mathrm{m} . n=6$ tanks, 1 fish/tank.

and Ahmad, 2009). On the contrary, feeding 25\% of Chlorella spp. or $23 \%$ of Scenedesmus spp. for 90 days led to poor growth, FCR and PER of Nile tilapia fingerlings (Badwy et al., 2008).

Studies have indicated the ability of carnivorous fish to make use of proteins from microalgae. Rainbow trout (Oncorhynchus mykiss) can tolerate up to $68 \%$ Spirulina (A. maxima, 35\% algal protein) (Matty and Smith, 1978). On the other hand, an eightweek feeding study on rainbow trout fry indicated a significant reduction in the growth of the fish that received 25 and $50 \%$ algae (a consortium of algal biomass consisting of Chlorophyceae and Cyanobacteria) in their diets (Dallaire et al., 2007). The authors concluded that the maximum incorporation level should be $12.5 \%$ to avoid negative effects on growth, body lipid and energy content of the fish. The growth and feed performance of longfin yellowtail (Seriola rivoliana) was affected upon feeding with the microalga Schizochytrium limacinum (Kissinger et al., 2016). Feeding European sea bass (Dicentrarchus labrax) with freeze-dried Isochrysis sp. did not alter the SGR, FCR, and PER of the fish (Tibaldi et al., 2015). These indices in gilthead sea bream (Sparus aurata) juveniles were also not affected by feeding with Scenedesmus almeriensis (38\%) (Vizcaíno et al., 2014). Similarly, feeding juvenile Atlantic salmon with land animal- or plantprotein based feeds that contained Spirulina meal (11\%) did not alter the growth, feed performance, and survival of the fish (Burr et al., 2012). On the contrary, Entomoneis spp. (5\%) in the diets of Atlantic salmon did not alter the growth or PER, but lowered the FCR (Norambuena et al., 2015). In the present feeding study, we did not observe any difference in either the specific growth rate (1.04-1.07) or protein efficiency ratio (2.32-2.36) of salmon that consumed the defatted meal of Desmodesmus sp.

Organosomatic indices are indicators of the general wellbeing of an organism (Dethloff and Schmitt, 2000). The HSI and VSI of sturgeon (Acipenser baeri) fed on 60\% of an Indian strain of Spirulina were 3.07 and 9.49, respectively; the VSI values were significantly higher than that of the control group (Palmegiano et al., 2005). Fifteen percent replacement of fishmeal with Spirulina pacifica in the diets of parrot fish (Oplegnathus fasciatus) also did not alter the HSI but increased the VSI compared to the control group (Sung-Sam et al., 2013).
Furthermore, the HSI value of longfin yellowtail was not altered by feeding with S. limacinum (Kissinger et al., 2016). In the present study, the VSI (8.1-8.3) and HSI (1.3) of the algal groups were not significantly different from the values of the control group.

The apparent digestibility coefficients of diets containing microalgae have been evaluated for farmed fishes. A study on European sea bass reported that the ADC values of protein, lipid and energy in the diets containing freeze-dried Isochrysis sp. (14\%) were 92.6, 87.6, and 85.0, respectively (Tibaldi et al., 2015). The digestibility of protein in fingerling mirror carp and rainbow trout feeds that contained $A$. maxima (68\%) were 87.1 and 83.1, respectively (Atack et al., 1979). In Atlantic salmon, the digestibility of protein and lipid of feeds containing Entomoneis spp. (5\%) were 83 and 87, respectively (Norambuena et al., 2015). The protein, lipid and energy digestibility values of an algal product made from Schizochytrium sp. (20\%) in the feeds of rainbow trout were 87.3, 53, and 60, respectively (Zhang, 2013). In the present study, the protein, lipid and energy digestibility values in the $20 \%$ alga-containing feeds were 84,94 , and 80 , respectively. The digestibility of energy of the feeds containing $10 \%$ alga was significantly different from that of the control feed. The lower digestibility of energy in the $4 \mathrm{~L}$ feed coincided with the lower final weights and the filet lipid content of the group. However, the higher inclusion of the alga did not cause a significant reduction in energy digestibility.

The protein, lipid and ash content of the whole body and filet of Atlantic salmon were analyzed. Algal feeding did not significantly alter the proximate composition of the whole body of Atlantic salmon, but the protein content in the whole body and fillet of the alga-fed groups was relatively higher and lower, respectivley. Feeding red sea bream (Pagrus major) for 95 days on a diet supplemented with $2 \%$ Spirulina sp. elevated the protein synthesis of the fish, and the stromal fraction of the muscle protein was significantly higher in the Spirulina-fed group (Mustafa et al., 1994). A study on Nile tilapia revealed that feeding $25 \%$ of Chlorella spp. or $23 \%$ of Scenedesmus spp. for 90 days lowered carcass protein content, but increased both fat and ash contents (Badwy et al., 2008). On the other hand, the protein and lipid content of the whole body of Nile tilapia fry fed on 
$10 \mathrm{~g}$ live A. platensis/kg of feed were significantly higher than the values of the control group (Abdel-Tawwab and Ahmad, 2009). The body protein content was higher, but the lipid content was lower in the Spirulina-fed Nile tilapia larvae/juveniles than the values in the control fish that were fed on corn gluten meal-based feed (Hussein et al., 2013). In the current study, the lipid and ash content were lower in the filet of Atlantic salmon fed 10 and $20 \%$ of Desmodesmus sp., respectively.

\section{Health Status upon Feeding Desmodesmus to Atlantic salmon}

Plant ingredients are associated with anti-nutritional factors, which can reduce the bioavailability of some nutrients and negatively affect the growth and health of fish. For instance, there are many anti-nutritional substances in soybean, and these are suspected to induce allergy and alter the growth of fish. It is reported that feeding rainbow trout with high levels $(60 \%)$ of soya or offering Atlantic salmon with $3.5 \%$ soybean agglutinin led to binding of the agglutinin to the intestinal enterocytes, which in turn caused aberrations of the intestinal structure of the carnivorous fishes (Buttle et al., 2001). One of the antinutritional factors, $\beta$-conglycinin was found to decrease the antioxidant capacity indices such as SOD, CAT, glutathioneS-transferase, glutathione peroxidase and glutathione reductase activities and glutathione content in the intestine and enterocytes of juvenile Jian carp (Cyprinus carpio) (Zhang et al., 2013). Furthermore, feeding Atlantic salmon with genetically modified maize is reported to elevate the SOD and CAT activity in the distal intestine of the fish (Sagstad et al., 2007). However, based on the results of the present study, Desmodesmus-feeding did not significantly alter the serum antioxidant indices (TAC, SOD and CAT) and the associated genes $(\operatorname{sod} 1, n r f 2)$ in the intestine of alga-fed groups. sod1 instructs the synthesis of SOD enzyme and nuclear factor erythroid 2-related factor 2 (Nrf2) controls the expression of antioxidant response element-dependent genes (Ma, 2013). GSTA2 (glutathione S-transferase A2) and NQO1 (NADPH: quinone oxidoreductase 1) are two Nrf2-regulated genes (Ma, 2013), and gstp1 and nqo1 were altered in zebrafish exposed to toxins (Lam et al., 2008).

Cytokines, namely TGF $\beta$ and IL10 are mediators of antiinflammatory responses, and tumor necrosis factor (TNF) and IL-17A are responsible for pro-inflammatory reactions. IL-17D is important in local immune responses and repair of tissues after structural damage (Starnes et al., 2002). il17a and $t f g b$ were upregulated in the intestine of Atlantic salmon during the early and/or late inflammatory stages (Marjara et al., 2012), and il1b was reduced after recovery from inflammation (Vasanth et al., 2015). Oral intubation of $10 \mathrm{mg}$ of $A$. platensis suspension per carp (C. carpio) increased the phagocytic activity, superoxide anion production, $i l 1 b$ and $t n f a$, but decreased illo in head kidney leukocytes (Watanuki et al., 2006). In the present study, the expression of $i l 1 b, \operatorname{tnfa}$, il17a and $i l 10$ were below the detection limit. Marjara et al. (2012) reported the low expression of certain genes including tnfa in the distal intestine of Atlantic salmon. In the present study, the mRNA levels of $t g f b$ and illid of the algal groups were similar to those of the control fish. The transcripts of $i l 1 b$ and $\operatorname{tnfa}$ were not altered in the intestine of Atlantic salmon fed olive oil, rapeseed oil or soybean oil (Moldal et al., 2014). However, soybean oil feeding was found to lower the igm and igt levels in the distal intestine of the fish (Moldal et al., 2014). The feeding of the algal biomass in this study did not alter the level of igt in the distal intestine of Atlantic salmon. Cathelicidins, a group of antimicrobial peptides, have been implicated in intestinal inflammatory conditions in humans (Schauber et al., 2006). In the present study, the mRNA levels of cathll and cathl 2 were higher than that in the control group, but not significantly different.

We did not observe any inflammatory signals in the micromorphology of the distal intestine. Similarly, feeding longfin yellowtail with S. limacinum (Kissinger et al., 2016) or gilthead sea bream with S. almeriensis (Vizcaíno et al., 2014) did not alter the intestinal morphology of the fishes.

There are not many studies that have examined the dietrelated changes in the intestinal proteins of fish. Distal intestinal proteins (Ahsg, My11, Dld) associated with immune defense, motility of actin filaments and energy metabolism were underexpressed in Atlantic salmon that consumed Desmodesmus sp. The functions of AHSG in humans include regulation of protease activity, pathogenesis of colorectal cancer, monocyte recruitment to bone, and bone metabolism (Crawford, 1984; Malone and Richards, 1987; Katsuhito et al., 2011; Fan et al., 2014). Upregulation of AHSG is considered as an indication of squamous cell carcinoma (Tian et al., 2015). Reduction in levels of this glycoprotein in the serum of protein-energymalnourished children was associated with stunted growth, and compromised defense ability (Abiodun et al., 1985). Although Ahsg was significantly lower in the $4 \mathrm{~L}$ and $4 \mathrm{H}$ groups, the growth of the fish and the expression of immune defense genes in the groups were not significantly different from those of the control group. A myosin type was also altered in the algal groups-myosins are motor proteins that bind to actin, and they convert chemical energy into mechanical work, which enables them to move along actin filaments (Heissler and Sellers, 2016). My11 heavy chain is expressed in the smooth muscle cells of the gastrointestinal tract of mammals, and the expression of the protein was unchanged by hypertrophy (Park et al., 2015), which is associated with inflammation (Blennerhassett et al., 1992). In the present study, My11 was underexpressed in the distal intestine of salmon fed $20 \%$ of Desmodesmus sp. and we did not observe any inflammation in the distal intestine. DLD is associated with energy metabolism, and this TCA cycleassociated protein was overexpressed in the gut of black tiger shrimp, Penaeus monodon, that were orally intubated with white spot syndrome viral antigens (Kulkarni et al., 2014). On the other hand, Dld was underexpressed in the alga-fed groups, significantly in the case of fish that received $10 \%$ of the algal biomass. Interestingly, the energy digestibility of feeds that contained the algal biomass was lower compared to that of the control feed, significantly in the case of feeds with $10 \%$ of the algal biomass. A decrease in Dld was suggested to help probiotic bacteria such as Lactobacillus fermentum to survive in the small 
intestine (Yang et al., 2007). The physiological relevance of the underexpression of the three proteins in the distal intestine needs to be verified through further studies.

\section{CONCLUSION}

Atlantic salmon is able to tolerate the defatted biomass from Desmodesmus sp. The results indicate that $20 \%$ inclusion level in the feeds of Atlantic salmon does not have any adverse effects on the specific growth rate, condition factor, protein efficiency ratio and whole body proximate composition of fish. Furthermore, the algal inclusion did not impair the health of Atlantic salmon, as evident from the physiological indices, molecular markers of inflammation and intestinal micromorphology. Future studies should consider evaluating the effects of algal inclusion above $20 \%$ in long-term feeding studies on salmon, after optimizing the ingredient and feed processing to increase the digestibility of algal nutrients and reduce the feed conversion ratio. Thus, the Desmodesmus biomass can effectively replace fishmeal in Atlantic salmon feeds. The defatted microalgal biomass can also be a potential ingredient in the feeds of other aquatic animals.

\section{AUTHOR CONTRIBUTIONS}

VK conceived and led this study, and wrote the manuscript. MS was involved in the experimental design and scientific discussions and edited the manuscript. As the leader of the

\section{REFERENCES}

Abdel-Tawwab, M., and Ahmad, M. H. (2009). Live Spirulina (Arthrospira platensis) as a growth and immunity promoter for Nile tilapia, Oreochromis niloticus (L.), challenged with pathogenic Aeromonas hydrophila. Aquacult. Res. 40, 1037-1046. doi: 10.1111/j.1365-2109.2009.02195.x

Abiodun, P. O., Ihongbe, J. C., and Dati, F. (1985). Decreased levels of alpha 2 HSglycoprotein in children with protein-energy-malnutrition. Eur. J. Pediatr. 144, 368-369. doi: 10.1007/BF00441779

Atack, T. H., Jauncey, K., and Matty, A. J. (1979). The utilization of some single cell proteins by fingerling mirror carp (Cyprinus carpio). Aquaculture 18, 337-348. doi: 10.1016/0044-8486(79)90037-1

Austreng, E. (1978). Digestibility determination in fish using chromic oxide marking and analysis of contents from different segments of the gastrointestinal tract. Aquaculture 13, 265-272. doi: 10.1016/0044-8486(78)90 008-X

Badwy, T. M., Ibrahim, E. M., and Zeinhom, M. M. (2008). "Partial replacement of fish meal with dried microalga (Chlorella spp. and Scenedesmus spp.) in Nile tilapia (Oreochromis niloticus) diets," in 8th International Symposium on Tilapia in Aquaculture (Cairo), 801-811.

Baeverfjord, G., and Krogdahl, A. (1996). Development and regression of soybean meal induced enteritis in Atlantic salmon, Salmo salar L., distal intestine: a comparison with the intestines of fasted fish. J. Fish Dis. 19, 375-387. doi: 10.1111/j.1365-2761.1996.tb00376.x

Bakke, A. (2011). "Pathophysiological and immunological characteristics of soybean meal-induced enteropathy in salmon: contribution of recent molecular investigations," in Avances en Nutrición Acuícola XI - Memorias del Décimo Primer Simposio Internacional de Nutrición Acuícola, eds L. E. Cruz-Suárez, D. Ricque-Marie, M. Tapia-Salazar, M. G. Nieto-López, D. A. Villarreal-Cavazos, J. Gamboa-Delgado, and L. Hernández-Hernández (Monterrey: Universidad Autónoma de Nuevo León), 345-372.
DoE project, $\mathrm{MH}$ participated in the project development and revised the manuscript. GV took care of the fish experiments and conducted the gene and protein studies. YG and AP performed the biochemical analysis. DD carried out the histological studies.

\section{ACKNOWLEDGMENTS}

We thank the Department of Energy (DoE), USA for funding the project "Large-scale production of fuels and feed from marine microalgae" (DE-EE0003371) that was awarded to the Cornell Marine Algae Biofuels Consortium. We thank all the members of the Cornell Marine Algae Biofuels Consortium, especially Charles Green, who led the team. Cellana, San Diego, USA is thanked for providing the algal biomass produced at their facilities in Kailua-Kona, Hawaii. The authors would like to acknowledge the support of the staff at the Research Station of Nord University.

\section{SUPPLEMENTARY MATERIAL}

The Supplementary Material for this article can be found online at: http://journal.frontiersin.org/article/10.3389/fmars. 2016.00067

Supplementary Figure 1 | Photomicrographs of the distal intestine of Atlantic salmon from the different study groups. Scale bar: $50 \mu \mathrm{m}$.

Supplementary Figure 2 | 2-DE gels and the volumes of the differentially expressed protein spots. *Different letters above the bar graphs indicate statistically significant differences. Values are presented as mean \pm s.e.m.

Bancroft, J. D., and Gamble, M. (2007). Theory and Practice of Histological Techniques. London, UK: Churchill Livingstone.

Becker, E. W. (2007). Micro-algae as a source of protein. Biotechnol. Adv. 25, 207-210. doi: 10.1016/j.biotechadv.2006.11.002

Becker, W. (2004). "Microalgae in human and animal nutrition," in Microalgal Culture, ed A. Richmond (Oxford: Blackwell Science Ltd.), 312-351.

Blennerhassett, M. G., Vignjevic, P., Vermillion, D. L., and Collins, S. M. (1992). Inflammation causes hyperplasia and hypertrophy in smooth muscle of rat small intestine. Am. J. Physiol. 262, G1041-G1046.

Burr, G. S., Wolters, W. R., Barrows, F. T., and Hardy, R. W. (2012). Replacing fishmeal with blends of alternative proteins on growth performance of rainbow trout (Oncorhynchus mykiss), and early or late stage juvenile Atlantic salmon (Salmo salar). Aquaculture 334-337, 110-116. doi: 10.1016/j.aquaculture.2011.12.044

Buttle, L. G., Burrells, A. C., Good, J. E., Williams, P. D., Southgate, P. J., and Burrells, C. (2001). The binding of soybean agglutinin (SBA) to the intestinal epithelium of Atlantic salmon, Salmo salar and rainbow trout, Oncorhynchus mykiss, fed high levels of soybean meal. Vet. Immunol. Immunopathol. 80, 237-244. doi: 10.1016/S0165-2427(01)00269-0

Crawford, S. M. (1984). Alpha-2 HS glycoprotein in the hypercalcaemia of multiple myeloma. Br. J. Cancer 49, 813-815. doi: 10.1038/bjc.1984.127

Dallaire, V., Lessard, P., Vandenberg, G., and de la Noüe, J. (2007). Effect of algal incorporation on growth, survival and carcass composition of rainbow trout (Oncorhynchus mykiss) fry. Bioresour. Technol. 98, 1433-1439. doi: 10.1016/j.biortech.2006.05.043

Dethloff, G. M., and Schmitt, C. J. (eds.). (2000). "Condition factor and organosomatic indices," in Information and Technology Report USGS/BRD-2000-0005: Biomonitoring of Environmental Status and Trends (BEST) Program: Selected Methods for Monitoring Chemical Contaminants and Their Effects in Aquatic Ecosystems (Columbia, IN: U.S. Geological Survey, Biological Resources Division), 13-18. 
Energy.Gov: Office of Energy Efficiency and Renewable Energy (2016). Biomass Feedstocks [Online]. U.S. Department of Energy. Available online at: http://energy.gov/eere/bioenergy/biomass-feedstocks (Accessed March 24, 2016).

Enzing, C., Ploeg, M., Barbosa, M., and Sijtsma, L. (2014). "Microalgae-based products for the food and feed sector: an outlook for Europe," eds M. Vigani, C. Parisi, and E. R. Cerezo (Luxembourg: European Commission, Joint Research Centre - Institute for Prospective Technological Studies), 78. Available online at: http://ftp.jrc.es/EURdoc/JRC85709.pdf

Fan, N. J., Kang, R., Ge, X. Y., Li, M., Liu, Y., Chen, H. M., et al. (2014). Identification alpha-2-HS-glycoprotein precursor and tubulin beta chain as serology diagnosis biomarker of colorectal cancer. Diagn. Pathol. 9, 53. doi: 10.1186/1746-1596-9-53

Heissler, S. M., and Sellers, J. R. (2016). "Myosins," in Encyclopedia of Cell Biology, eds R. A. Bradshaw and P. D. Stahl (Waltham, MA: Academic Press), 597-607. doi: 10.1016/B978-0-12-394447-4.20059-X

Huntley, M. E., Johnson, Z. I., Brown, S. L., Sills, D. L., Gerber, L., Archibald, I., et al. (2015). Demonstrated large-scale production of marine microalgae for fuels and feed. Algal Res. 10, 249-265. doi: 10.1016/j.algal.2015.0 4.016

Hussein, E. E.-S., Dabrowski, K., El-Saidy, D. M. S. D., and Lee, B.-J. (2013). Enhancing the growth of Nile tilapia larvae/juveniles by replacing plant (gluten) protein with algae protein. Aquacult. Res. 44, 937-949. doi: 10.1111/j.13652109.2012.03100.x

Katsuhito, M., Masanori, E., and Masaaki, I. (2011). Fetuin-A: a multifunctional protein. Recent Pat. Endocr. Metab. Immune Drug Discov. 5, 124-146. doi: 10.2174/187221411799015372

Kiron, V., Phromkunthong, W., Huntley, M., Archibald, I., and De Scheemaker, G. (2012). Marine microalgae from biorefinery as a potential feed protein source for Atlantic salmon, common carp and whiteleg shrimp. Aquacult. Nutr. 18, 521-531. doi: 10.1111/j.1365-2095.2011.00923.x

Kissinger, K. R., García-Ortega, A., and Trushenski, J. T. (2016). Partial fish meal replacement by soy protein concentrate, squid and algal meals in low fishoil diets containing Schizochytrium limacinum for longfin yellowtail Seriola rivoliana. Aquaculture 452, 37-44. doi: 10.1016/j.aquaculture.2015.10.022

Knudsen, D., Urán, P., Arnous, A., Koppe, W., and Frøkiaer, H. (2007). Saponincontaining subfractions of soybean molasses induce enteritis in the distal intestine of Atlantic salmon. J. Agric. Food Chem. 55, 2261-2267. doi: $10.1021 /$ jf0626967

Kulkarni, A. D., Kiron, V., Rombout, J. H. W. M., Brinchmann, M. F., Fernandes, J. M. O., Sudheer, N. S., et al. (2014). Protein profiling in the gut of Penaeus monodon gavaged with oral WSSV-vaccines and live white spot syndrome virus. Proteomics 14, 1660-1673. doi: 10.1002/pmic.201300405

Lam, S. H., Mathavan, S., Tong, Y., Li, H., Karuturi, R. K. M., Wu, Y., et al. (2008). Zebrafish whole-adult-organism chemogenomics for large-scale predictive and discovery chemical biology. PLoS Genet. 4:e1000121. doi: 10.1371/journal.pgen.1000121

Ma, Q. (2013). Role of Nrf2 in oxidative stress and toxicity. Annu. Rev. Pharmacol. Toxicol. 53, 401-426. doi: 10.1146/annurev-pharmtox-011112-140320

Malone, J. D., and Richards, M. (1987). a2HS glycoprotein is chemotactic for mononuclear phagocytes. J. Cell. Physiol. 132, 118-124. doi: $10.1002 /$ icp. 1041320116

Marjara, I. S., Chikwati, E. M., Valen, E. C., Krogdahl, Å., and Bakke, A. M. (2012). Transcriptional regulation of IL-17A and other inflammatory markers during the development of soybean meal-induced enteropathy in the distal intestine of Atlantic salmon (Salmo salar L.). Cytokine 60, 186-196. doi: 10.1016/j.cyto.2012.05.027

Matty, A. J., and Smith, P. (1978). Evaluation of a yeast, a bacterium and an alga as a protein source for rainbow trout: I. Effect of protein level on growth, gross conversion efficiency and protein conversion efficiency. Aquaculture 14, 235-246. doi: 10.1016/0044-8486(78)90097-2

Moldal, T., Løkka, G., Wiik-Nielsen, J., Austbø, L., Torstensen, B. E., Rosenlund, G., et al. (2014). Substitution of dietary fish oil with plant oils is associated with shortened mid intestinal folds in Atlantic salmon (Salmo salar). BMC Vet. Res. 10:60. doi: 10.1186/1746-6148-10-60
Mustafa, M. G., Umino, T., and Nakagawa, H. (1994). The effect of Spirulina feeding on muscle protein deposition in red sea bream, Pagrus major. J. Appl. Ichthyol. 10, 141-145. doi: 10.1111/j.1439-0426.1994.tb00153.x

National Research Council of the National Academies (2011). Nutrient Requirements of Fish and Shrimp. Washington, DC: The National Academies Press.

Norambuena, F., Hermon, K., Skrzypczyk, V., Emery, J. A., Sharon, Y., Beard, A., et al. (2015). Algae in fish feed: Performances and fatty acid metabolism in juvenile Atlantic salmon. PLoS ONE 10:e0124042. doi: 10.1371/journal.pone. 0124042

Norges Standardiseringsforbund (1994). "Norsk Standard 9402E", in Atlantic Salmon Colour and Fat Measurement (Oslo).

Palmegiano, G. B., Agradi, E., Forneris, G., Gai, F., Gasco, L., Rigamonti, E., et al. (2005). Spirulina as a nutrient source in diets for growing sturgeon (Acipenser baeri). Aquacult. Res. 36, 188-195. doi: 10.1111/j.1365-2109.2005.01 209.x

Park, C., Lee, M. Y., Park, P. J., Ha, S. E., Berent, R. M., Fuchs, R., et al. (2015). Serum response factor is essential for prenatal gastrointestinal smooth muscle development and maintenance of differentiated phenotype. $J$. Neurogastroenterol. Motil. 21, 589-602. doi: 10.5056/jnm15063

Sagstad, A., Sanden, M., Haugland, Ø., Hansen, A. C., Olsvik, P. A., and Hemre, G. I. (2007). Evaluation of stress- and immune-response biomarkers in Atlantic salmon, Salmo salar L., fed different levels of genetically modified maize (Bt maize), compared with its near-isogenic parental line and a commercial suprex maize. J. Fish Dis. 30, 201-212. doi: 10.1111/j.1365-2761.2007.00 808.x

Schauber, J., Rieger, D., Weiler, F., Wehkamp, J., Eck, M., Fellermann, K., et al. (2006). Heterogeneous expression of human cathelicidin hCAP18/LL-37 in inflammatory bowel diseases. Eur. J. Gastroenterol. Hepatol. 18, 615-621. doi: 10.1097/00042737-200606000-00007

Starnes, T., Broxmeyer, H. E., Robertson, M. J., and Hromas, R. (2002), Cutting edge: IL-17D, a novel member of the IL-17 family, stimulates cytokine production and inhibits hemopoiesis. J. Immunol. 169, 642-646. doi: 10.4049/jimmunol.169.2.642

Sung-Sam, K., Rahimnejad, S., Kang-Woong, K., and Kyeong-Jun, L. (2013). Partial replacement of fish meal with Spirulina pacifica in diets for parrot fish (Oplegnathus fasciatus). Turkish J. Fish. Aquat. Sci. 13, 197-204. doi: 10.4194/1303-2712-v13_2_01

Tian, W.-D., Li, J.-Z., Hu, S.-W., Peng, X.-W., Li, G., Liu, X., et al. (2015), Proteomic identification of alpha-2-HS-glycoprotein as a plasma biomarker of hypopharyngeal squamous cell carcinoma. Int. J. Clin. Exp. Pathol. 8, 9021-9031.

Tibaldi, E., Chini Zittelli, G., Parisi, G., Bruno, M., Giorgi, G., Tulli, F., et al. (2015). Growth performance and quality traits of European sea bass (D. labrax) fed diets including increasing levels of freeze-dried Isochrysis sp. (T-ISO) biomass as a source of protein and n-3 long chain PUFA in partial substitution of fish derivatives. Aquaculture 440, 60-68. doi: 10.1016/j.aquaculture.2015.02.002

Vandesompele, J., De Preter, K., Pattyn, F., Poppe, B., Van Roy, N., De Paepe, A., et al. (2002). Accurate normalization of real-time quantitative RT-PCR data by geometric averaging of multiple internal control genes. Genome Biol. 3, research0034.0031-research0034.0011. doi: 10.1186/gb-2002-3-7-research0034

Vasanth, G., Kiron, V., Kulkarni, A., Dahle, D., Lokesh, J., and Kitani, Y. (2015). A microbial feed additive abates intestinal inflammation in Atlantic salmon. Front. Immunol. 6:409. doi: 10.3389/fimmu.2015.00409

Vizcaíno, A. J., López, G., Sáez, M. I., Jiménez, J. A., Barros, A., Hidalgo, L., et al. (2014). Effects of the microalga Scenedesmus almeriensis as fishmeal alternative in diets for gilthead sea bream, Sparus aurata, juveniles. Aquaculture 431, 34-43. doi: 10.1016/j.aquaculture.2014.05.010

Watanuki, H., Ota, K., Tassakka, A. C. M. A. R., Kato, T., and Sakai, M. (2006). Immunostimulant effects of dietary Spirulina platensis on carp, Cyprinus carpio. Aquaculture 258, 157-163. doi: 10.1016/j.aquaculture.2006.0 5.003

Yang, F., Wang, J., Li, X., Ying, T., Qiao, S., Li, D., et al. (2007). 2-DE and MS analysis of interactions between Lactobacillus fermentum I5007 and intestinal epithelial cells. Electrophoresis 28, 4330-4339. doi: 10.1002/elps.200700166 
Ytrestøyl, T., Aas, T. S., and Åsgård, T. (2015). Utilisation of feed resources in production of Atlantic salmon (Salmo salar) in Norway. Aquaculture 448, 365-374. doi: 10.1016/j.aquaculture.2015. 06.023

Zhang, C. (2013). Determination of the Digestibility of a Whole-Cell DHA-Rich Algal Product and Its Effect on the Lipid Composition of Rainbow Trout and Atlantic salmon. Saskatoon: University of Saskatchewan.

Zhang, J.-X., Guo, L.-Y., Feng, L., Jiang, W.-D., Kuang, S.-Y., Liu, Y., et al. (2013). Soybean $\beta$-conglycinin induces inflammation and oxidation and causes dysfunction of intestinal digestion and absorption in fish. PLoS ONE 8:e58115. doi: 10.1371/journal.pone.0058115
Conflict of Interest Statement: The authors declare that the research was conducted in the absence of any commercial or financial relationships that could be construed as a potential conflict of interest.

Copyright (c) 2016 Kiron, Sørensen, Huntley, Vasanth, Gong, Dahle and Palihawadana. This is an open-access article distributed under the terms of the Creative Commons Attribution License (CC BY). The use, distribution or reproduction in other forums is permitted, provided the original author(s) or licensor are credited and that the original publication in this journal is cited, in accordance with accepted academic practice. No use, distribution or reproduction is permitted which does not comply with these terms. 